\title{
HUMAN FOOT PERSPIRATION AND .UPPER LEATHER
}

\author{
By A. COLIN-RUSS, Pн.D., F.I.C. \\ From the Research Laboratories of The British Boot, Shoe \\ and Allied Trades Research Association
}

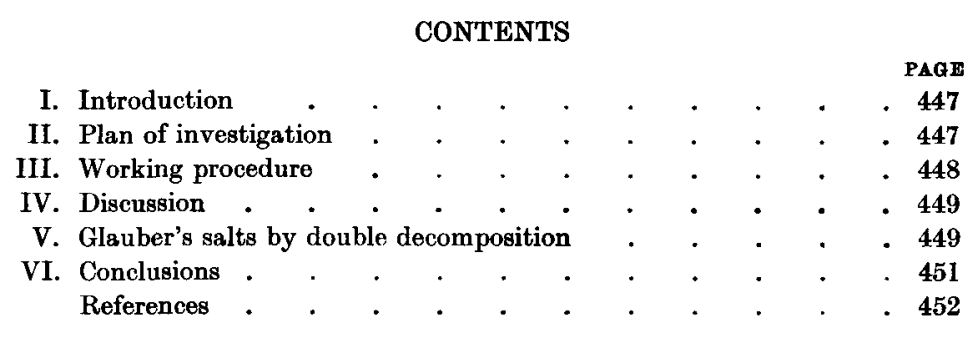

\section{InTRODUCTION}

THE suspicion, long entertained, that the grey or white deposit on a large amount of worn footwear, returned with complaint of "spewing salt" on the vamps, had its origin in the action of foot perspiration, has been confirmed during the last ten years.

Since sodium sulphate was frequently the predominant, and sometimes the only, constituent, the question arose as to how exactly this was derived through the agency of the wearer's perspiration. In many of the cases examined in detail the various component materials of the shoes were free from excess quantities of Glauber's salts. Although the production of uric acid or sugar by gouty or diabetic subjects was borne in mind, the deposition of Glauber's salts due to cathartic disposition was considered unlikely.

\section{Plan of investigation}

In an investigation by the author (1935) on the nature of human foot perspiration, an example was given of a synthetic perspiration, made for the purpose of conveniently advancing further studies on the reactions with materials clothing the foot. In this investigation use has been made not only of this synthetic preparation (minus the small quantity of sulphate), but also lactic acid B.P. and sodium chloride Anala R.

Lactic acid alone was chosen in view of its detanning effect, characteristic of all hydroxy-acids which abstract some of the chromium from upper leather. Although it was present in the synthetic foot perspiration, it was desirable to learn the accentuated effect caused by a high concentration of this acid, say $10 \%$ aqueous. 
The concentration of the sodium chloride in normal perspiration is sufficiently high to warrant noting its effect on the upper, and in order to make the observations strictly comparable with the foregoing, a chemically equivalent strength was chosen, namely, $6.5 \%$ aqueous.

To complete the comparison, observations were made with a $10 \%$ aqueous preparation of the synthetic perspiration. In 100 c.c. of this preparation, the total solids can be represented by a hypothetical accumulation of similar solids under natural conditions extending over a period of 5-10 weeks. This consideration arises from the experience gained by the author in previous work (1935).

Chrome leather, considered simply as the result of the tanning action on prepared collagen protein by a chrome solution rendered partly basic, may introduce complications due to the variable extent of association of hydroxy groups with the chrome complex fixed on the protein fibre. Consequently, to safeguard against such complications, two chrome upper leathers were chosen (box calf) of high and low basicities. Thus, taking $\mathrm{Cr}_{2}(\mathrm{OH})_{6}$ (which fails to tan) as of basicity $100 \%$, the selected box-calf samples had basicities of 82.2 and $65.9 \%$; they had been tanned with chrome liquors which had received an alkaline treatment sufficient to cause only partial displacement of the $\mathrm{SO}_{4}$ radical by hydroxy groups.

Observations were performed at 100,35 , and $18^{\circ} \mathrm{C}$., so as to elicit what might occur to leather under normal and drastic conditions.

\section{WORKING PROCEDURE}

The following is a brief description of the procedure.

Lots of leather weighing $5 \mathrm{~g}$. cut into pieces, $0 \cdot 25 \mathrm{~cm}$. sq., were treated at the desired temperature with 100 c.c. of the reagent for $1 \mathrm{hr}$. After cooling, if necessary, the liquid portion was decanted and the residue thoroughly washed. The total liquid was then clarified with "Hyflo"- a proprietary white siliceous filter-aid remarkably free from soluble matterand filtered with suction through a paper circle resting flat inside a Gooch crucible. No clarification was required for the sodium chloride extracts.

Next, the sulphate was quantitatively separated from the filtrate, and the further filtrate obtained evaporated, ashed, fused and iodimetrically titrated for chromium.

In the case of the hot extractions with the lactic acid reagent, the amount of chromium was sufficient to warrant treating one-quarter to one-half only of the clarified filtrate, which was made for convenience to a total bulk of 200 c.c.

In the case of the extracts made with $6.5 \% \mathrm{NaCl}$, it was desirable in the determination of chromium, first of all to evaporate down to 25 c.c. approximately and then to precipitate off most of the chlorides, including the small excess of barium precipitant, by the addition of an equal bulk of concentrated $\mathrm{HCl}$ Anala $\mathrm{R}$. The saline precipitate was rinsed with further amounts of strong acid, and the collected liquids evaporated to dryness before soda fusion.

Controls on the lactic acid and sodium chloride reagents as well as on the synthetic perspiration, revealed complete absence of sulphate, so that no corrections were necessary in determining the losses suffered by the leather samples. 
The accompanying table summarizes the losses in sulphate and chromic oxide from which are calculated the residual basicities, i.e. basicities of the leather remaining unattacked after $1 \mathrm{hr}$. treatment, and also percentage losses expressed in terms of the original content of chromic oxide or total sulphate.

The residual basicities are calculated from the ratio $100(1-b / a)$, where $b$ and $a$ are the volumetric equivalents of $\mathrm{SO}_{4}$ and $\mathrm{Cr}$ remaining. These equivalents arise directly in the formol method of Riess \& Papayannis (1933) used for determining the original basicities. In the case of $b$, allowance is of course made for losses which include $\mathrm{SO}_{4}$ due to sodium already in the free state and represented by the very small quantity of "ashed water-solubles" content of the leather. It may be here noted that, although such an allowance is theoretically sound and essential, the amount of free sodium sulphate which can be liberated into solution in $1 \mathrm{hr}$. at temperatures below $100^{\circ} \mathrm{C}$. rarely attains $0.2 \%$, and is a mere trace at ordinary temperatures; the full quantity of free sulphate can be liberated only by lengthy boiling over at least $3 \mathrm{hr}$.

\section{Discussron}

1. In all cases rise of temperature, as would be expected, brings about increased decomposition of the leather.

2. The residual basicities are in all cases more than the original and increase with rise of temperature, except under the lactic acid treatment where there is a slight decrease.

3. Sodium chloride causes the greatest loss in sulphate whatever the temperature and nearly completes the action at $100^{\circ} \mathrm{C}$.

4. By contrast with the foregoing action, lactic acid causes the greatest loss in chromic oxide and is nearly complete at $100^{\circ} \mathrm{C}$.

5. The leather with the greater basicity is on the whole more resistant to losses in combined chromium and sulphate.

6. Synthetic perspiration as used in $10 \%$ strength contains only 0.034 time the acid in an equal volume of the $10 \%$ lactic acid, and only 0.0065 time the equivalent sodium chloride reagent of equal volume. Yet in a comparison at $35^{\circ} \mathrm{C}$. - the temperature of a warm foot-it accounts for approximately one-tenth the chromic oxide lost by the treatment with the acidic reagent, and as much as one-half the sulphate by the saline reagent. At $100^{\circ} \mathrm{C}$., the corresponding fraction for chromic oxide is 0.04 and for sulphate $0 \cdot 6$. Such figures vividly illustrate the potent action on the leather uppers of foot perspiration as a whole.

\section{GLaUber's Salts by double Decomposition}

Although the complex nature of both the collagen protein and the chrome tanning liquor makes the theoretical consideration of their mutual fixation difficult, because of the numerous factors governing such fixations, yet it is useful to consider fixation by the primary and auxiliary valencies of chromium to the collagen protein as well as to its own hydroxy and acid groups. 
The action of perspiration fluid involves also the introduction of sodium ions from the saline ingredients. Therefore, any release from the chrome leather of ionizable $\mathrm{SO}_{4}$ under the saline influence, whether or not accompanied by the liberation of hydrogen ions due to hydrolysis, must necessarily result in the formation of sodium sulphate. Broadly speaking, the process may be considered as double decomposition in the following symbolic manner:
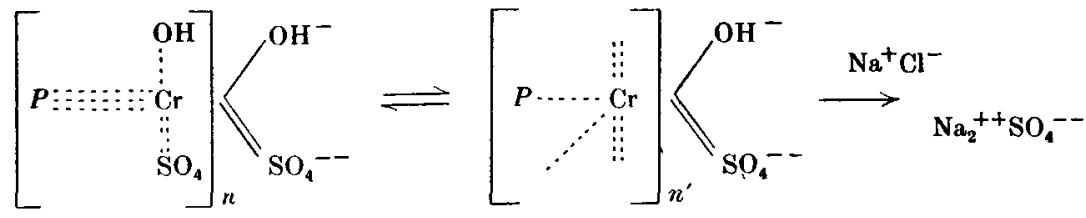

where $P$ denotes collagen inclusive of water molecules as well as of its own active groups such as $\mathrm{NH}_{2}, \mathrm{OH}, \mathrm{COOH}$ and zwitterions. $n$ and $n^{\prime}$ depend on the degree of aggregation, whilst no assumptions are made regarding the extent of co-ordinated $\mathrm{OH}$ or $\mathrm{SO}_{4}$ radicals or what fractions of these become ionizable when the different aggregates are in a state of dynamic equilibrium.

Table 1 gives a practical idea of such decomposition. Taking the case of leather no. 613 , the perspiration reactant releases at $35^{\circ} \mathrm{C}$., the temperature of a warm foot, no less than $0.39 \times 142 / 96 \mathrm{~g}$. of sodium sulphate or $0.58 \%$ of the leather weight. Now it is empirically agreed amongst leather chemists

\section{Table 1}

\begin{tabular}{|c|c|c|c|c|c|c|c|c|c|c|c|c|c|c|}
\hline \multirow[b]{3}{*}{ Reactant } & \multicolumn{7}{|c|}{ Box calf no. 613} & \multicolumn{7}{|c|}{ Box calf no. $583 / \mathrm{E}$} \\
\hline & \multicolumn{3}{|c|}{ Sulphates lost } & \multicolumn{3}{|c|}{ Chromic oxide lost } & \multirow[b]{2}{*}{$\begin{array}{c}\text { Residual } \\
\text { basicity } \\
\%\end{array}$} & \multicolumn{3}{|c|}{ Sulphates lost } & \multicolumn{3}{|c|}{ Chromic oxide lost } & \multirow[b]{2}{*}{$\begin{array}{c}\text { Residual } \\
\text { basicity } \\
\%\end{array}$} \\
\hline & g. & $\begin{array}{l}\text { c.c. } \\
N / 10 \\
\text { per g. }\end{array}$ & $\begin{array}{l}\% \text { of } \\
\text { total }\end{array}$ & g. & $\begin{array}{l}\text { c.c. } \\
N / 10 \\
\text { per g. }\end{array}$ & $\begin{array}{l}\% \text { of } \\
\text { total }\end{array}$ & & g. & $\begin{array}{l}\text { c.c. } \\
N / 10 \\
\text { perg. }\end{array}$ & $\begin{array}{l}\% \text { of } \\
\text { total }\end{array}$ & g. & $\begin{array}{l}\text { c.c. } \\
N / 10 \\
\text { per g. }\end{array}$ & $\begin{array}{l}\% \text { of } \\
\text { total }\end{array}$ & \\
\hline \multicolumn{15}{|l|}{ Lactic acid, \%: } \\
\hline At $100^{\circ} \mathrm{C}$ & $2 \cdot 02$ & $4 \cdot 21$ & $100 \cdot 0$ & $2 \cdot 29$ & 9.05 & $85 \cdot 8$ & $\begin{array}{l}\text { Disinte- } \\
\text { grated }\end{array}$ & $1 \cdot 43$ & $2 \cdot 99$ & $68 \cdot 7$ & $4 \cdot 32$ & $17 \cdot 07$ & $74 \cdot 8$ & $81 \cdot 4$ \\
\hline $\begin{array}{l}35^{\circ} \mathrm{C} \\
18^{\circ} \mathrm{C}\end{array}$ & $\begin{array}{l}0 \cdot 31 \\
0 \cdot 12\end{array}$ & $\begin{array}{l}0 \cdot 65 \\
0.24\end{array}$ & $\begin{array}{r}15 \cdot 6 \\
5.8\end{array}$ & $\begin{array}{l}0.44 \\
0.03\end{array}$ & $\begin{array}{l}1 \cdot 72 \\
0 \cdot 12\end{array}$ & $\begin{array}{r}16 \cdot 3 \\
1 \cdot 1\end{array}$ & $\begin{array}{c}60 \cdot 3 \\
65.5\end{array}$ & $\begin{array}{l}0 \cdot 15 \\
0.05\end{array}$ & $\begin{array}{l}0 \cdot 31 \\
0 \cdot 10\end{array}$ & $\begin{array}{l}7 \cdot 1 \\
2 \cdot 3\end{array}$ & $\begin{array}{l}0.52 \\
0.08\end{array}$ & $\begin{array}{l}2 \cdot 05 \\
0 \cdot 30\end{array}$ & $\begin{array}{l}9 \cdot 0 \\
1 \cdot 3\end{array}$ & $\begin{array}{l}80 \cdot 5 \\
82 \cdot 0\end{array}$ \\
\hline \multicolumn{15}{|c|}{ Synthetic perspiration, \%: } \\
\hline $\begin{array}{r}\text { At } 100^{\circ} \mathrm{C} . \\
35^{\circ} \mathrm{C} . \\
18^{\circ} \mathrm{C} .\end{array}$ & $\begin{array}{l}1.09 \\
0.39 \\
0.04\end{array}$ & $\begin{array}{l}2 \cdot 27 \\
0 \cdot 81 \\
0 \cdot 08\end{array}$ & $\begin{array}{r}54 \cdot 6 \\
19 \cdot 5 \\
1.9\end{array}$ & $\begin{array}{l}0.09 \\
0.04 \\
0.004\end{array}$ & $\begin{array}{l}0 \cdot 36 \\
0 \cdot 16 \\
0 \cdot 02\end{array}$ & $\begin{array}{l}3 \cdot 4 \\
1 \cdot 5 \\
0 \cdot 2\end{array}$ & $\begin{array}{l}81 \cdot 5 \\
67 \cdot 8 \\
65 \cdot 8\end{array}$ & $\begin{array}{l}0.95 \\
0 \cdot 25 \\
0 \cdot 11\end{array}$ & $\begin{array}{l}1.98 \\
0.53 \\
0.22\end{array}$ & $\begin{array}{r}45 \cdot 5 \\
12 \cdot 2 \\
5 \cdot 1\end{array}$ & $\begin{array}{l}0.31 \\
0.04 \\
0.01\end{array}$ & $\begin{array}{l}1 \cdot 24 \\
0 \cdot 18 \\
0 \cdot 04\end{array}$ & $\begin{array}{l}5 \cdot 5 \\
0 \cdot 8 \\
0 \cdot 2\end{array}$ & $\begin{array}{l}89 \cdot 0 \\
83 \cdot 1 \\
82 \cdot 2\end{array}$ \\
\hline \multicolumn{15}{|c|}{ Sodium chloride, $6.5 \%$ : } \\
\hline At $\begin{aligned} 100^{\circ} \mathrm{C} . \\
35^{\circ} \mathrm{C} \\
18^{\circ} \mathrm{C} .\end{aligned}$ & $\begin{array}{l}1.78 \\
0.75 \\
0.42\end{array}$ & $\begin{array}{l}3 \cdot 70 \\
1.56 \\
0.88\end{array}$ & $\begin{array}{l}88 \cdot 9 \\
37 \cdot 5 \\
21 \cdot 2\end{array}$ & $\begin{array}{l}0 \cdot 35 \\
0 \cdot 30 \\
0 \cdot 15\end{array}$ & $\begin{array}{l}0 \cdot 14 \\
0 \cdot 12 \\
0 \cdot 06\end{array}$ & $\begin{array}{l}1.3 \\
1.1 \\
0.6\end{array}$ & $\begin{array}{l}95 \cdot 6 \\
75 \cdot 1 \\
68 \cdot 7\end{array}$ & $\begin{array}{l}1 \cdot 60 \\
0 \cdot 63 \\
0.37\end{array}$ & $\begin{array}{l}3.32 \\
1.32 \\
0.77\end{array}$ & $\begin{array}{l}76 \cdot 3 \\
30 \cdot 4 \\
17 \cdot 7\end{array}$ & $\begin{array}{l}0.02 \\
0.01 \\
0.005\end{array}$ & $\begin{array}{l}0.08 \\
0.04 \\
0.02\end{array}$ & $\begin{array}{l}0 \cdot 4 \\
0 \cdot 2 \\
0 \cdot 1\end{array}$ & $\begin{array}{l}95 \cdot 5 \\
86 \cdot 7 \\
84 \cdot 25\end{array}$ \\
\hline Original: & & & & & & & $\begin{array}{c}\text { Original } \\
\text { basicity } \\
\%\end{array}$ & & & & & & & $\begin{array}{c}\text { Original } \\
\text { basicity } \\
\%\end{array}$ \\
\hline Chromic oxide & $e-$ & - & - & $2 \cdot 67$ & $10 \cdot 55$ & - & - & - & - & - & $5 \cdot 76$ & $22 \cdot 80$ & - & - \\
\hline $\begin{array}{l}\mathrm{SO}_{4} \text { com- } \\
\text { bined }^{*}\end{array}$ & 1.73 & $3 \cdot 60$ & - & - & - & 一 & - & 1.94 & $4 \cdot 04$ & - & - & - & - & - \\
\hline $\mathrm{SO}_{\text {, free }}$ & $0 \cdot 27$ & $0 \cdot 56$ & - & - & - & 一 & - & $0 \cdot 15$ & $0 \cdot 31$ & 一 & 一 & - & - & - \\
\hline Basicity, \% & 一 & 一 & 一 & 一 & 一 & - & $65 \cdot 9$ & - & - & - & - & - & - & $82 \cdot 2$ \\
\hline
\end{tabular}


that an amount beyond $0.5 \%$ is undesirable if, as the result of the washing action on the salt through the vamp creases by the moisture of perspiration, spewing is to be avoided. Before wear, this particular leather would reveal only $0.4 \%$ sulphate in the free state, as ascertained after $3 \mathrm{hr}$. treatment with boiling water. At $100^{\circ} \mathrm{C}$, the release by the synthetic perspiration is as much as $1.06 \%$. Thus, a foot which perspires freely at a higher temperature than $35^{\circ} \mathrm{C}$, is likely during a period of 1-2 hr., to cause sulphate formation of between 0.6 and $1.06 \%$ of the upper leather.

As an extreme instance of what might be released over a sufficient length of time by perspiration which in the case of any particular individual happens to be rich in the saline ingredient, the table reveals at $35^{\circ} \mathrm{C}$. an amount equal to $0.75 \times 142 / 96$ or $1.1 \%$ sulphate. The lactic acid reactant, as the table shows, would release at the same temperature $0.46 \%$. It follows, therefore, that a cool foot which fatigues easily may perspire sufficiently to cause spewing, since fatigue often involves some rise of temperature.

Similar conclusions could be drawn from a study of the other leather sample. Certainly, at ordinary temperatures spewing may not occur in many individual circumstances, even if sodium sulphate and a chrome-lactate complex are formed. There is every probability, however, that in the meantime, local rigidity of the leather pores may occur as a result of absorption of the substances released. The walls of such pores would then crack under flexure of the shoe upper when walking. Such crackiness is more easily observed on brown or other coloured chrome upper leather rather than on black, because the initial effect is in the form of a dark matt stain.

Independently of the above considerations, various attempts have been made to analyse the matter worked into such local parts. It was considered possible, for instance, that sodium bi-sulphate, or a special chrome compound or even a double combination might be found but, so far, only normal sodium sulphate has been detected, and as regards the chromium, too little was available in the quantity set free from the upper for identification of its exact form.

There has not yet been opportunity to investigate the problem with other types of chrome upper material manufactured with formate, acetate, chloride and other acid radicals in place of sulphate.

\section{Conclusions}

Human foot perspiration has a pronounced twofold effect on full-chrome upper leathers of the type usually met with, namely those tanned with basic chrome sulphate liquors.

The acidic and saline constituents of the perspiration disrupt the collagen complex and cause progressive release of both solubilized chromium and ionizable sulphate.

The higher the temperature, and apparently also when the tannage is more basic, the greater is the extent of such release with a freely perspiring foot. 
Ultimately, in its simplest terms, perspiration is conceived to interact with the leather by double decomposition resulting in the formation of sodium sulphate, which may, or may not, become visible as a "spew", or as an effect of crackiness (brittle leather fibre).

It is nevertheless of interest to raise the question as to how much acid radical is co-ordinated or how much is ionizable, both before and after treatment of the chrome leather with perspiration. The more deeply this problem is probed the greater is seen to be the vista of possibilities, which may finally have an important practical bearing on the suitability of upper material clothing the foot.

The compilation of the table necessitated much tedious analysis of a specialized character, and the author has pleasure in acknowledging the assistance of his colleague, Mr W. H. F. Jackman, B.Sc., A.I.C.

\section{REFERENCES}

Colin-Russ, A. (1935). Human foot perspiration, its nature and interactions with footwear. J. Hyg., Camb., 35, 199-206.

Riess \& Papayannis (1933). Collegium, p. 719.

(MS. received for publication 16. II. 40.-Ed.) 